\title{
Southern African pasture and forage science entering the 21st century: past to present
}

\author{
Wayne F Truter $^{1 *}$, Philip R Botha ${ }^{2}$, Chris S Dannhauser ${ }^{3}$, Barbara V Maasdorp ${ }^{4}$, Neil Miles ${ }^{5}$, Albert Smith ${ }^{6}$, Hennie A \\ Snyman $^{7}$ and Neil M Tainton ${ }^{8}$ \\ ${ }^{1}$ Department of Plant Production and Soil Science, University of Pretoria, Pretoria, South Africa \\ 2 Directorate Plant Sciences, Western Cape Department of Agriculture, Outeniqua Research Farm, George, South Africa \\ ${ }^{3}$ Grass SA, Waverley, Pretoria, South Africa \\ ${ }^{4}$ Department of Crop Science, University of Zimbabwe, Harare, Zimbabwe \\ ${ }^{5}$ South African Sugarcane Research Institute, Mount Edgecombe, South Africa \\ ${ }^{6}$ Stats4science, Pretoria, South Africa \\ 7 Department of Animal, Wildlife and Grassland Sciences, University of the Free State, Bloemfontein, South Africa \\ ${ }^{8}$ Amber Valley, Howick, South Africa \\ * Corresponding author, e-mail: wayne.truter@up.ac.za
}

Given the global challenges of mitigating and alleviating land degradation and ensuring food security, particularly through protein production, pasture and forage science together with rangeland science will remain imperative to sustainable livestock production systems. Recognising the scientific principles developed in this discipline the past $\mathbf{5 0}$ years and more in Southern Africa, customary to our diverse and unique environmental conditions will continue to guide and identify future research priorities. A journey from the past to the present can assist in avoiding reinvention and repetition of pasture research. This review highlights how research priorities have either remained the same over time or where research has received less or more priority. The review further illustrates that there has been more interest in species adaptation to drought, pasture and forage water relations, alternative pasture and forage species, and the combination of pasture species in the 21st century than in the 20th century. In conclusion, the soil-plant-livestock complex can serve as a conceptual basis for more effective research together with pasture breeding and nutrition. Finally, researching pasture and forage sciences in an inter- and multi-disciplinary manner clearly supports the principles of holism applied by General JC Smuts, one of the first pioneers of pasture and forage sciences.

Keywords: alternative species, drought adaptation, forage, livestock production systems, pasture, water relations

\section{Introduction}

Confucius once said that there are three methods we learn wisdom: firstly, by reflection, which is the noblest; secondly, by imitation, which is the easiest; and thirdly, by experience, which is the bitterest.

The purpose of this review is to highlight how research priorities in pasture and forage sciences have evolved in southern Africa from the early 20th century into the second decade of the 21st century. Peer-reviewed scientific publications of the Grassland Society of Southern Africa form the basis of the review, which (1) identifies the main fields of pasture and forage science research, (2) evaluates and prioritises the main findings and progress within each of these research fields, and (3) makes recommendations regarding future research priorities.

The history of southern African pasture and forage sciences has created a steady foundation for the further growth and development of this discipline in the 21st century. This science, together with rangeland science (which is not discussed in this paper), will remain and become a more important component of a sustainable solution in ensuring food security in the world, by means of animal production and degraded land rehabilitation.

\section{A reflection on the 20th century}

In $1888 \mathrm{~F}$ Blersch, the principal of the Agricultural School at the Victoria College, in Stellenbosch, identified the need for improved pasture plants. In the early 1900s research on pasture species escalated. Co-operative trials were initiated with farmers and much attention was given to subtropical grasses (Hall 1934).

Towards the end of the decade in 1907-1908, the increased need for winter pastures was identified. Many reports concluded that imported grasses were performing better than natural species. The year 1908 saw the introduction of some of our well-known exotic species, with no further 
records of evaluation. It was only following the recommendations of the final report of the well-known Drought Investigation Commission in 1923 that pasture research became more formalised. An important recommendation was to institute an effective programme of research and extension to address the deterioration of soil, veld and water resources, which was so evident in South Africa at the time (Tidmarsh 1966).

In 1934, after a serious drought in 1933, the first small pasture research service in the former Department of Agriculture and Forestry was instituted, under the leadership of Dr IB Pole Evans and supported by the Prime Minister General JC Smuts (himself a passionate botanist and naturalist) (Tidmarsh 1966; Donaldson 1984). The period 1910 to 1934 yielded few pasture research publications in South Africa. During the Second World War (1941 to 1945) a shortage in fertiliser and staff resulted in existing experiments being temporarily discontinued. This delay in agricultural research was seen throughout South Africa (Gildenhuys 1951).

The earliest recommendations on pasture breeding were made in 1861 (Scott 1975; Smith and Rhind 1984). In 1910 the first documented introductions and evaluations took place on selections of Pennisetum clandestinum (kikuyu) and Festuca sp. (New Zealand tall fescue) (Burtt-Davy 1912). This was followed by a breeding programme on a local indigenous species viz. Digitaria eriantha (Smuts finger grass) (de Villiers 1934).

During 1953, after considerable expansion of staff and facilities, Rietondale (Gauteng province) emerged as the main grass breeding centre. By 1958 there were 2600 varieties of grasses being evaluated and a group of plant breeders were engaged in the development of improved pasture crops (Anon. 1958). The breeding of a new variety of a pasture crop can take up to 15 years, and in view of a severe shortage of seed in the early 1950s, it was decided to give preference to the selection of apomictic crops. A pasture legume breeding programme then commenced in 1976 at Cedara near Pietermaritzburg, KwaZulu-Natal (Smith and Rhind 1984).

In the 1950s South Africa was regarded as being (predominantly) a pastoral country, in which livestock production contributed significantly to the gross agricultural income of the country. Therefore, an active programme on radical veld improvement (the conversion of veld into improved pasture, without having to resort to traditional methods of seedbed preparation, involving soil cultivation) accepted the presence of suitable, well-adapted plant species and cultivars for introduction into the natural veld. This programme continued to develop the need for research on herbage plant breeding and improvement (Smith and Rhind 1984).

An estimated $90 \%$ of the farm land was at that time under veld, approximately $65 \%$ of which fell in the semi-arid and arid regions of the country. It was clear that of all the factors responsible for plant growth and agricultural production, moisture supply would be the most limiting, a scenario still existing today. A major research objective was the conservation of moisture and improving efficiency of pasture utilisation. Tidmarsh (1966) summarised the problem as not 'to make two blades of grass grow where one grew before' but 'to make one drop of water grow what two drops of water grew before.'

At an inaugural meeting of the Grassland Society in 1966, several research priorities were identified and a more systematic approach to research was proposed. The bulk of the research would be aimed to provide more forage per unit area. It was anticipated at the time that livestock and crop production would be integrated on a much larger scale, into the diverse veld types in the agro-ecological regions of South Africa as identified by Acocks (1953), with pasture ley as the intermediate phase. These discussions resulted in many programmes being conducted on key research priorities identified in the period 1966-1999, as listed in Table 1.

With the foundation set in the 1960s, the need to increase production and quality of pastures realised, the importance of improved soil fertility through fertilisation with chemicals, organic and even agricultural waste materials was then of interest. Questions on sward replacement, a greater attention to the trace element status of the soil rather than only the major growth elements, and the incorporation of more efficient nitrogen ( $\mathrm{N}$ )-fixing legumes arose.

A more vigorous policy of herbage breeding was regarded essential, as well as the introduction of exotic species with higher value and growth potential. The conservation of fodder became increasingly important, as drought is, and was, an important feature of the South African climate and accepted as an integral part of the environment. Pasture improvement, by selecting more palatable and higher-quality pasture species, was followed by introducing the concept of combining species of different qualities. The question remained, however, on which was the best method to utilise these pastures.

In the 1970s little progress was being made with improved pastures, as reflected in the rising concerns of the members of the Grassland Society. Birch (1972) concluded that the value of veld was overrated for animal production, with severe limitations including low yield and poor palatability. Much work was focused all over the country on investigating legumes, and the selection and introduction of better-quality grass species.

Barnes et al. (1972) helped shape the way forward in evaluating and selecting forage species by introducing a sequence of techniques to facilitate this process. This included an initial phase, where species were introduced into nurseries and underwent preliminary screening, followed by the second phase of evaluation where the best species from Phase 1 were tested under different utilisation regimes such as mowing and grazing. Species that appeared promising in Phase 2 were investigated further in herbage production trials in Phase 3, to establish their growth potential and forage quality such as palatability and digestibility. Lastly, the best species selected from the previous phases were subjected to animal production trials in Phase 4 . Here the stocking rates, suitable grazing systems, required level of supplemental feeding, level of fertilisation and type, age, sex and condition of animals were evaluated. With the selection of new species research on evaluating the method of utilisation and the defoliation effects on the species remained essential (Barnes et al. 1972).

The soil-plant-animal complex, however, could serve as a conceptual basis for more effective research (Barnes 1973). 
Table 1: Key research priorities of the 20th century as published in the various conference proceedings and journals of the Grassland Society of Southern Africa (1966-1999)

\begin{tabular}{lc}
\hline Selected 20th century research priorities & Reference \\
\hline Plant community classification & Grunow (1966), Gibbs Russell and Smook (1980) \\
Pasture utilisation & Booysen (1966), Booysen (1969), Rethman et al. (1977), Bransby and Tainton (1979), \\
& Dannhauser (1988), Gammon and Tiddy (1990), Mentis (1991), Snyman (1994), van \\
Legume species evaluation and production & Heerden and Durand (1994) \\
& Davies (1968), l'Ons (1968), West (1968), Savory (1972), Wasserman (1974), Clatworthy
\end{tabular}

Legume species evaluation and production (1975), l'Ons (1977), van Heerden and Tainton (1987), Le Roux and Howe (1988), Le Roux et al. (1988), Muir (1993)

Water use and efficiency of irrigated pasture and forage crops

Forage quality

Roberts and Scott (1968), l'Ons (1968), West (1968), Scott (1975), Steynberg et al. (1993), Snyman (1994), Theron and van Rensburg (1998)

Theron and Booysen (1966), Roberts (1967), l'Ons (1968), West (1968), Grunow et al. (1977), Miles et al. (1995)

Drought-tolerant fodder crops

Alternative forage and fodder species

Combined pastures

De Kock (1967), Donaldson (1990), Snyman (1994)

Rethman and Heyns (1987), Verschoor and Rethman (1992)

l'Ons (1968), West (1968), Grunow and Rabie (1978), van Denberg and Kruger (1989), Harris and Bartholomew (1991)

Pasture nutrition and fertilisation

Tainton et al. (1981), Rethman and de Witt (1984), Miles (1991), Miles and Manson (1992), Snyman (1994), van Heerden and Durand (1994)

Pasture planning and economics

Booysen (1972), Broom (1973), Heard and Wiseman (1973), Jones and Bartholomew (1973), Booysen et al. (1975), Tainton (1976)

Pasture breeding

Animal production and performance

De Villiers (1934), Rhind and Goodenough (1976a, 1976b), Smith (1977), Smith and Rhind (1984), Goodenough et al. (1988)

Bransby et al. (1977), Rethman et al. (1977), Clatworthy and Holland (1979), Edwards (1980), Heard et al. (1984), Karnezos et al. (1988)

Fodder conservation

Pasture evaluation and monitoring techniques

Anti-quality factors and animal health

Jones (1983), Dannhauser (1988), Hardy et al. (1990), de Figueiredo (1991), Le Roux and Dannhauser (1999)

Muzzell and Booysen (1969), Barnes et al. (1972), Inman-Bamber and Tainton (1972), Grunow and Rabie (1977), Austin et al. (1981), Eckard et al. (1988), Daphne et al. (1991)

Eckard (1990), Henaar et al. (1993), Pienaar et al. (1993), Eckard and Dugmore (1994)

At the time it was suggested that researchers had reached a plateau in terms of manipulative possibilities for increased production, and that research should be directed to understanding pasture species within, and their contribution to, production systems. This thinking was greatly supported by the fact that the objective of pasture production was animal production, but not at the expense of the environment.

The 1970s also saw the positive contributions of plant breeding programmes that assessed and bred tropical and temperate species. Investigating the utilisation intensity of these new pastures and the plant growth response within animal production systems then received attention. One of the outcomes of the aforementioned work initiated research using more intensive, accurate and quicker pasture evaluation techniques that provided data which could eventually be used in simulation modelling to predict pasture growth responses. It became evident that proper pasture planning was important and the use of annual production curves opened the way forward to computerised methods of pasture planning. In subsequent years this would translate into and become an important aspect of fodder flow budgeting.

The 1980s delivered a few challenges, both academically and practically. Gibbs Russell and Smook (1980) introduced botanical name changes for 227 species in the 25 years since Chippindall's (1955) 'Guide to the identification of grasses'. This was in addition to the inclusion of an additional 1791 species published for southern Africa and accepted by the National Herbarium at the Botanical Research Institute, Pretoria (PRE). With a much broader knowledge of species in the country, this decade of research addressed the need to understand rainfall variability, and the tolerance and adaptation of species to drought (Donaldson 1984).

Bransby (1984) posed the same question a decade later as Birch had in 1972, of why there had been so little progress in improved pastures. Possible reasons then included the high cost of establishment and maintenance of pastures, the doubtful economic feasibility of pastures to farmers, and the lack of incentive for farmers to expand production by intensification. Partly as a result of Bransby's analysis, the 1980s was the decade where much emphasis was placed on improving pasture quality, highlighting the need for the inclusion of alternative forage species, other than pasture grasses or legumes.

Towards the end of the century, action was taken on some of the reflections of the past 60 years of pasture and forage research. From here, it became evident that attention should be given to evaluating currently acceptable measurement techniques that would improve the understanding of pasture growth responses to various management inputs and changing environmental conditions. Furthermore, research into methods to improve the production and quality 
of intensively managed pasture grasses and legumes continued. This research concentrated on the efficient use of combined pastures, irrigation, nutrients, herbicides, inoculants and undesired resultant effects on animal health and consequently on their production.

The research highlights, programmes and fundamental principles established in the pasture research period of the 20th century were on many tropical/subtropical and temperate pasture and forage species. The species researched extensively in the 20th century in southern Africa are listed in Table 2. The ranking was conducted quantitatively, searching the Grassland Society databases using species names.

Smit (1998) posed the question whether, after 70 years of pasture research and 35 years of a professional society for grassland scientists, pasture and forage science was becoming extinct. This question emphasised major challenges ahead, yet great opportunities for scientists and specialists in the 21 st century.

\section{Entering the 21st century}

At the beginning of the new millennium, Kirkman (2000) confirmed how a changing environment had placed pressure on the discipline of pasture science. South African research budgets had been cut, and pasture specialists were being lost to countries with greater research opportunities, resulting in a loss of research capacity in South Africa. Nationally, institutions that had traditionally employed pasture scientists (e.g. universities, departments of agriculture and research institutions) refocused their priorities and resources. Figure 1 shows both the changing research priorities in the 21 st century relative to the 20th century, as well as the decline in the rate of publications on pasture research in the last 15 years.

Pasture and forage breeding in the 20th century received high priority and new cultivars were selected. The animal performance and consequently the economic value of pastures were of importance. This picture has, however, changed significantly and, due to the lack of both breeding programmes and integrated economic analyses of pasture production systems, these priorities are currently recognised as critically essential. With the cost of fertilisers rising, pasture nutrition will continue to be an important research priority, but with a greater emphasis on economic efficiency and soil health through research into mixed grass-legume systems and alternative sources of nutrients such as animal wastes. Alternative nutrient systems will affect forage quality, which will require strict monitoring, especially on animal health and production. In the light of changing environmental conditions, the necessity of identifying drought-tolerant pasture and fodder crops became important, together with the understanding of plant water and nutrient use relations under dry land and irrigated conditions.

Unquestionably, the future research challenges provide new opportunities to be explored using different approaches. With the threat of diminishing resources and expertise in the pasture science discipline, it is vital to align future research priorities to environmental, social and economic challenges in order for research programs to remain relevant and justify budget allocations.
Table 2: Top ranking (most to least) researched pasture and forage species of the 20th century in southern Africa

\begin{tabular}{ll}
\hline Tropical and subtropical species & Temperate species \\
\hline Grasses and other forage species & \\
Eragrostis curvula & Lolium multiflorum \\
Pennisetum clandestinum & Festuca arundinacea \\
Digitaria eriantha & Lolium perenne \\
Cenchrus ciliaris & Dactylis glomerata \\
Cynodon dactylon & Phalaris spp. \\
Antephora pubescens & Bromus spp. \\
Panicum maximum & \\
Chloris gayana & \\
Cynodon aethiopicus / C. nlemfuensis & \\
Atriplex nummularia & \\
Legumes & \\
Desmodium uncinatum & \\
Stylosanthes guyanensis & Trifolium repens \\
Desmodium intortum & Medicago sativa \\
Macroptilium atropurpureum & Trifolium pratense \\
Neonotonia wightii & Trifolium subterraneum \\
Leucaena leucocephala & Medicago spp. (annual) \\
Lablab purpureus & \\
Lotononis bainesii & \\
& \\
Twenty-first century research priorities identified from \\
20th century findings
\end{tabular}

Some key research priorities for the 21st century were identified from the literature reviewed (Table 3). Further discussion will focus on six of the highest ranking priorities, which are linked to one another and are regarded as key principles for the further development of pasture and forage science, in changing environmental conditions in southern Africa. These are pasture and forage breeding, pasture nutrition, the role of subtropical and tropical legumes in animal production, increasing water use efficiency of pastures, and the integration of temperate and/or subtropical pastures in animal production systems.

\section{Pasture and forage breeding}

With no further pasture breeding programmes continuing in the 21st century, some key aspects are highlighted from historical research. Although the objectives of forage plant improvement have been broadly defined since 1888, it is important to take into account that a normal breeding programme for a cross-pollinating crop takes about 15 years before release as a commercial cultivar. This can only be achieved if continuity is obtained when a principal forage breeding centre is established, as Cedara was in the 1950s (Cornell 1951).

By 1972, many temperate grass and one temperate legume cultivar had been commercially released. It was the decision in the 1980s that priority species need to receive attention, since they were identified for the eastern high potential areas of southern Africa. These species remain the most important, used and evaluated species, and include the grasses Eragrostis curvula, Pennisetum clandestinum, Lolium multiflorum, Dactylis glomerata, Festuca arundinacea, Cynodon spp. and Digitaria eriantha, and the legumes Medicago sativa, Trifolium repens and T. pratense (Anon. 1981). 


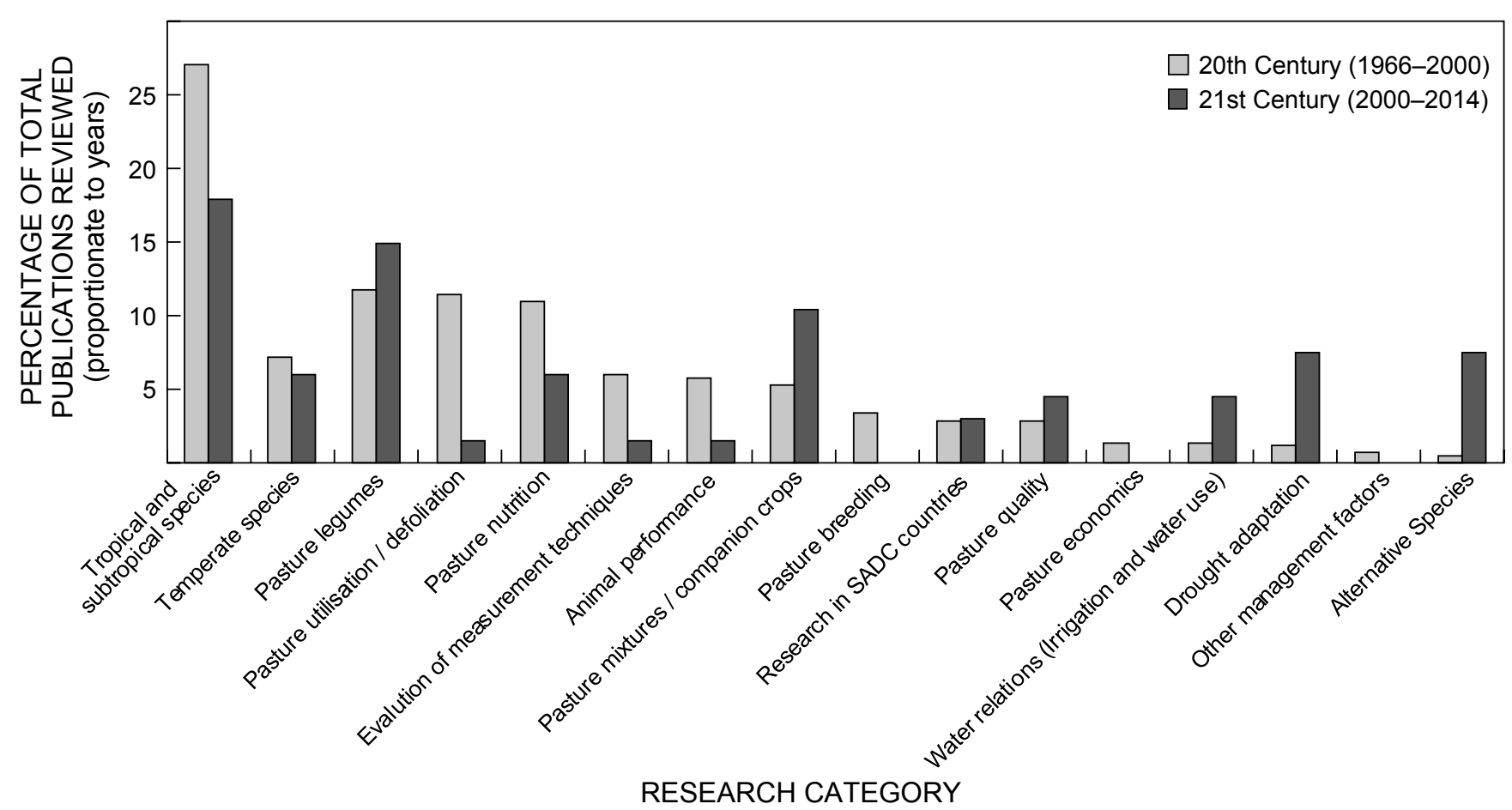

Figure 1: Percentage research publications on different research priorities (1966-2014)

Table 3: Summary of research and developmental needs identified from this review

\begin{tabular}{|c|c|}
\hline \multicolumn{2}{|c|}{ Research and development needs } \\
\hline Sustainable production systems & Forage breeding programmes \\
\hline $\begin{array}{l}\text { Integrated animal, crop and } \\
\text { forage systems }\end{array}$ & Drought-tolerant species \\
\hline Natural resource conservation & $\begin{array}{l}\text { Species adaptation to degraded } \\
\text { soils }\end{array}$ \\
\hline Ecosystem services & $\begin{array}{l}\text { Alternative legume species } \\
\text { evaluation }\end{array}$ \\
\hline Pasture crop modelling & $\begin{array}{l}\text { Species adaptation to climate } \\
\text { change }\end{array}$ \\
\hline $\begin{array}{l}\text { Advanced pasture monitoring } \\
\text { techniques }\end{array}$ & $\begin{array}{l}\text { Maintain and improve germplasm } \\
\text { collection }\end{array}$ \\
\hline Anti-quality factors & Water and nutrient use efficiency \\
\hline
\end{tabular}

The first temperate legume cultivar to be bred in South Africa, white clover ( $T$. repens) 'Dusi', was bred at Cedara in a breeding programme aimed at improving drought and acid tolerance and the lifespan of the clover in pastures (Smith and Morrison 1983). A large number of ryegrass (Lolium spp.) cultivars were released and selections were eventually made on characteristics, not only based on plant production, but also on the nutritional value of the cultivars (Rhind and Goodenough 1976b). The release of the cultivar 'Enhancer' was a breakthrough in ryegrass breeding, not only for South Africa, but potentially for livestock production worldwide (Marais et al. 2003). The increased energy and nutritional value of this cultivar was far superior to any annual ryegrass (L. multiflorum) developed. Goodenough et al. (1988) continued to work on selecting tall fescue ( $F$. arundinacea) varieties for palatability, using multiple selection criteria including the relative softness of the leaves and grazing trials. These authors showed that cultivars with softer leaves were preferentially selected by grazing animals.

The national subtropical grass breeding programme, however, was aimed at the improvement of Smuts finger grass $(D$. eriantha), resulting in a commercially successful cultivar, 'Tip Top'. The only other preliminary evaluation of a non-commercial indigenous species conducted in South Africa has been on Sporobolus fimbriatus. As a pasture crop it was concluded that the growth rate and the leaf-to-stem ratio of $S$. fimbriatus varied considerably between seasons, but was, however, more acceptable under non-grazing conditions (du Pisani and Knight 1988).

Challenging leguminous pasture breeding led to a large number of lucerne ( $M$. sativa) cultivars being imported into South Africa. With a distinct lack of grazing tolerance of most of the imported hay-producing cultivars, the then Lucerne Control Board funded a selection and breeding programme, led by the Agricultural Research Council (ARC) - Range and Forage Institute, which was based on the lucerne cultivar 'SA Standard'. The result of this programme was the successful cultivar 'SA Select' (Smith and Terblanche 1994).

It is clear from the literature review that pastures and forage breeding programmes in most of southern Africa are no longer in alignment with international breeding programmes. This research and development need is regarded as high priority, should southern Africa wish to identify local varieties much more adapted to their environmental and management conditions.

\section{Pasture nutrition}

The potential for animal production from natural grassland in southern Africa is only a fraction of that attainable from 
cultivated intensive pastures. Such pastures are highly productive systems, which require high rates of energy and nutrient flow. High rates of energy flow are achieved by using photosynthetically efficient plants, while high rates of nutrient flow are achieved through nutrient additions to the system. Additions of nutrients are mainly by the application of fertiliser and lime, biological $\mathrm{N}$ fixation and animal deposition of dung and urine containing nutrients from feeds imported onto the farm.

Nitrogen is quantitatively the most important element derived from the soil by pasture plants. In South Africa, the bulk of the $\mathrm{N}$ requirement is supplied through fertilisers. Although legumes are widely included in intensive pastures, generally poor predictability of legume growth has led to limited reliance on legumes as a source of $\mathrm{N}$ for grass growth. Over the past four decades, scores of field trials conducted throughout South Africa and in Zimbabwe have confirmed the responsiveness of pasture grasses to $\mathrm{N}$, and revealed that where moisture and other nutrients are not limiting, $\mathrm{N}$ requirements for maximum production are often in excess of $250 \mathrm{~kg} \mathrm{~N}$ ha $^{-1} \mathrm{y}^{-1}$ (Hyam and Clayton 1968; Parkin and Boultwood 1980; Bartholomew and Miles 1982; Rethman et al. 1984; Rethman 1987; Eckard 1989; Miles and Manson 2000).

In terms of dry matter (DM) yield, the pattern of response of grass pastures to applied $\mathrm{N}$ is characterised by near-linear yield increases with increasing increments of $\mathrm{N}$, followed by diminishing returns, then a levelling-off of the response curve and finally a decline. The amount of DM produced for each kilogram of $\mathrm{N}$, applied within the initial linear response zone, has been shown to depend on the species under consideration, the frequency of defoliation and growth conditions (Miles and Manson 2000). Tropical grasses produce more DM per unit of $\mathrm{N}$ than temperate grasses. Eragrostis curvula, for example, produces up to $61 \mathrm{~kg} \mathrm{DM} \mathrm{kg}^{-1} \mathrm{~N}$ applied (Tainton et al. 1981), but irrigated ryegrasses only between 25 and $34 \mathrm{~kg} \mathrm{DM} \mathrm{kg}^{-1} \mathrm{~N}$ applied (Eckard 1989). The optimum stocking rate increases with the increasing herbage production in response to increasing $\mathrm{N}$.

The topsoils of pastures, and particularly of perennial pastures such as kikuyu, contain large amounts of $\mathrm{N}$ (Miles and Manson 2000). As much as $98 \%$ of this $\mathrm{N}$ is bound in soil organic matter and so is not immediately available to plants. Predictions of the fraction of these organic $\mathrm{N}$ reserves that are made available for plant growth are often unreliable, and are a source of uncertainty in the derivation of fertiliser $\mathrm{N}$ recommendations, particularly under grazing conditions.

Phosphorus $(\mathrm{P})$ and potassium $(\mathrm{K})$ requirements of pastures have been evaluated in numerous field trials, mainly in the summer rainfall areas of the country. In their virgin state, most soils in South Africa are severely deficient in available $P$, and substantial fertiliser $P$ additions are required to ensure pasture persistence and productivity. In addition, significant differences exist between pasture species in both their ability to extract $P$ from the soil and in their overall $P$ requirements for growth. In general, legumes utilise soil $P$ less efficiently than grasses, in terms of extraction and DM response, and therefore have a higher soil $P$ requirement (Miles and Manson 2000). Of increasing concern is widespread evidence of the topsoils of many intensive pastures containing excessively high $\mathrm{P}$ levels. Soil test $P$ values are often an order of magnitude or more higher than established critical levels, for optimum pasture growth (Swanepoel et al. 2014a), which raise the possibility of significant $P$ losses to underground and surface water bodies, and thereby accelerated eutrophication of these waters.

Long-term $\mathrm{K}$ requirements of pastures are closely linked to the method of pasture utilisation. Under 'cutting-andremoval' management, large amounts of $\mathrm{K}$ are removed and fertiliser $\mathrm{K}$ requirements are commensurately large (Miles and Hardy 1999). However, under grazing, the bulk of the ingested $\mathrm{K}$ is returned to the pasture, and additional $K$ requirements are generally low or negligible (depending on the amount of time animals spend on the pasture). Relatively little research has been conducted into the sulphur (S) and micronutrient requirements of pastures in South Africa. Given the importance of these nutrients from both the plant growth and animal performance perspectives, there is clearly scope for additional work in this area.

High acidity, through its promotion of the solubility of aluminium (Al), has a widespread limiting effect on pasture production in the higher rainfall areas of southern Africa, with soluble Al being the most serious growth-limiting factor in acid soils. Control of soil acidity is effectively facilitated by liming. Pasture species have been found to differ widely in their responses to acid soil conditions. Relative differences in tolerances to soil acidity are known, highlighting the greater sensitivities to soil acidity of temperate pasture species than tropical species (Miles 1986; Miles and Manson 2000). While temperate species such as white clover ( $T$. repens) and perennial ryegrass ( $L$. perenne) may perform reasonably well in the short term, under mildly acid conditions, they fail to persist where soil acidity problems have not been adequately addressed. Tropical legumes are also sensitive to soil acidity, though less so than temperate species, related to decrease nutrient availability (Miles and Manson 2000).

High-quality intensive pastures improve animal production largely because their forage is high in metabolisable energy and protein. However, animal production on pastures producing high DM yields does not always meet expectations, as a number of factors may bring about imbalances in the organic and mineral components of the forage. Pasture species, stage of growth, soil type, climate, fertiliser and lime usage have all been found to have a considerable influence on herbage composition (Miles and Manson 2000). The latter findings on the nutritional requirements of pastures have highlighted the following areas of concern in terms of forage quality:

(1) Increasing the supply of $\mathrm{N}$ to pastures usually results in marked increases in the protein and nitrate content of grasses, and decreases in non-structural carbohydrates (Eckard 1989; Eckard and Dugmore 1994; Nash et al. 2008).

(2) Nitrogen levels greater than $4 \%$ of the DM are not unusual in intensive pastures, and are potentially toxic to ruminants due to the high levels of both protein and nitrate. Under these conditions, poor animal performance (which may include reduced fertility) may result from energy stress since rumen microbes require 
energy to metabolise the extra $\mathrm{N}$. High $\mathrm{N}$ forage may also lead to the forage being temporarily rejected due to an ammonia appetite repression mechanism.

(3) From a ruminant nutritional perspective, widespread deficiencies of calcium ( $\mathrm{Ca}$ ) and magnesium ( $\mathrm{Mg}$ ), and excesses of $\mathrm{K}$ in the herbage of intensive pastures are cause for concern (Bredon 1980; Miles et al. 1995, 2005).

(4) Imbalances of these minerals may pose serious limitations to the productivity of animals on pastures. Unfortunately, all too little attention appears to have been afforded to herbage mineral balances in the management of pasture nutrition. The economics of high $\mathrm{N}$ fertilised pastures have often resulted in investigations into the inclusion of legumes in intensive pastures. As previously mentioned, poor predictability of legume growth has also led to limited reliance on legumes, as a source of $\mathrm{N}$ for grass growth. The value of the legume in the pasture is rather in the improved combined forage quality.

\section{Subtropical and tropical forage legume contributions to improved animal production systems}

Research has focused on species introduction, evaluation, environmental adaptation, establishment, grazing impacts and animal production. The early aim of forage legume research was to provide feed for the dry-season deficit period, following recognition that tropical grasses could not sustain animals through the late dry season (Kulich and Kaluba 1985). It was, however, found that reserving grasslegume pastures or legume-reinforced veld for grazing in the dry season was wasteful due to frost and trampling (Clatworthy 1985), and Oxley fine stem stylo (Stylosanthes hippocampoides), for example, was shaded out when left unutilised for any length of time (Clatworthy and Muyotcha 1980). Better effects on animal production were achieved with year-round or growing-season use. Steers grazing year round were observed to select legumes as a major part of their diet from late summer and into the dry season. In a grass-legume pasture, this selective grazing improved DM digestibility by $10 \%$ (Mufandaedza 1981). The grazing regime was found to encourage legume persistence and high legume yields in rotational grazing systems, with grazing periods of not $>2$ weeks and rests of at least five weeks (Clatworthy 1985). Observations with fine stem stylo and silverleaf desmodium (Desmodium uncinatum) are that they will withstand burning (Maclaurin and Grant 1987). Pure legume stands are prone to weed invasion (Clatworthy and Muyotcha 1980), which reinforces their presence in grass pastures.

Subtropical and tropical forage/fodder legumes can be grouped into the following categories: annual herbaceous, perennial herbaceous, and shrubs/trees.

(1) Annual herbaceous legumes: Velvet bean (Mucuna pruriens var. utilis), a vigorous twining legume, was popular as a green manure crop in the early-mid 20th century and also used for grazing by dairy cows, especially in the autumn (Maasdorp et al. 2002). Late maturity types grow well into the dry season, until frosted. Lablab/dolichos bean (Lablab purpureus) and semi-trailing/trailing types of cowpea (Vigna unguiculata) are similar to velvet bean in growth habit, but cowpea is earlier flowering and not as useful as an early dry season forage. Cowpea is poor at regrowing (a regrowing/grazing cultivar, 'Encore', resulted from the ARC forage breeding programme at Roodeplaat). The regrowth of velvet bean and lablab are better following grazing than cutting and, if used leniently, lablab can be encouraged to grow through a second season. All exhibit good tolerance of low soil fertility. Lablab and cowpea are known for their drought resistance, particularly lablab, but recently velvet bean introduced into semi-arid areas has been growing well and proving popular with smallholder livestock producers for making hay used to see their animals through the dry season. Hay of these legumes is an ideal protein supplement for poor-quality roughages, resulting in improved rumen microbial growth and modest live weight gains at $20 \%$ inclusion (Mupangwa 2000). In subhumid areas, velvet bean has the advantage of high seed yields (average $1.5 \mathrm{t} \mathrm{ha}^{-1}$ on smallholder farms; Maasdorp et al. 2004), the grain also being used in concentrate rations for ruminants. Velvet bean, lablab and cowpea, as well as forage soya bean, have also been successfully intercropped with maize, forage sorghum and/or elephant grass (Napier fodder) to improve their forage value, particularly for silage. Growing the two crops separately with mixing at the silage pit may be preferable on a larger scale, but intercropping is of advantage for smallholders with limited land. Legume inclusion of at least $40 \%$ is needed, which raised maize silage crude protein from $7.7 \%$ to $11.3 \%$ in a study by Titterton and Maasdorp (1997). Sunnhemp species (Crotalaria juncea and C. ochroleuca), though usually used as a green manure crop, can also be used as a forage crop, providing they are grazed/fed not later than early flowering to ensure good digestibility.

(2) Perennial herbaceous legumes: The following species have proved well adapted to subhumid conditions on a wide range of soils: siratro (Macroptilium atropurpureum) in warmer areas, silverleaf desmodium (D. uncinatum) under slightly cooler and wetter conditions, and macro (Macrotyloma axillare), which is less cold-sensitive than silverleaf (Robinson and Clatworthy 1980). These are twining or trailing species. Oxley fine stem stylo and roundleaf cassia (Chamaecrista rotundifolia) grow best on sandy soils in subhumid and moderately semi-arid conditions and, due to their semi-prostrate growth habit, are fairly resistant to heavy grazing, even under communal grazing conditions (Clatworthy 1985). The deep taproots of all these species render them very resilient to drought, growing well into the dry season and sprouting again as temperatures rise before the summer rains in Zimbabwe (Maasdorp 2004). These perennial herbaceous legumes, in veld or pasture, can replace expensive protein-rich winter supplements and can replace or decrease the need for pen-fattening of beef cattle. Legume forage can also upgrade carcass quality. They also replace $\mathrm{N}$ fertiliser needs of grass to a considerable extent: the $\mathrm{N}$ contribution of silverleaf grown with star grass (Cynodon nlemfuensis) is estimated to be about $100 \mathrm{~kg} \mathrm{~N}$ ha $^{-1}$ with about $50 \%$ 
legume in the sward (estimated from Spear 1985). Perennial herbaceous legumes can be used for veld 'reinforcement' where grazing management is good: the twining/trailing types are more readily grazed out than those with a semi-prostrate growth habit. With a stocking rate of about $20 \%$ higher on reinforced veld than on non-reinforced veld, legume reinforcement increased body mass gains per hectare by an average of $53 \%$, animals on unsupplemented veld losing weight in the dry season (Clatworthy and Holland 1979). With supplementary summer irrigation in highveld areas a good combination is kikuyu grass ( $P$. clandestinum) and Kenya white clover (Trifolium semipilosum), extending the season by some months (Clatworthy 1985).

(3) Legume shrubs/trees: We can conveniently differentiate between two types of leguminous shrubs and trees, viz. short-lived shrubs and long-lived trees. Shrubs and trees have the advantage of a very long growing season, due to their deep roots, as well as being multipurpose (fodder, green manure, stakes, poles, fuelwood, and profuse flowers for bee fodder in the case of Acaciella angustissima [Acacia angustissima]). Sesbania (Sesbania sesban) and woody types of pigeonpea (Cajanus cajan) will persist for up to about 4-5 years (Maasdorp 2004). Sesbania is renowned for its fast growth and tolerance of waterlogging. Both are used in 'improved tree fallows' but can also provide fodder, when cut to leave some leafy branches to support regrowth. The true trees include several Leucaena species (e.g. L. leucocephala, L. esculenta, L. pallida and L. trichandra), Acaciella angustissima (non-thorny), Calliandra calothyrsus and Gliricidia sepium, and these take about four years to reach full production (Maasdorp 2004). Leucaena leucocephala is better adapted to warmer wetter sites though it still grows quite well in cooler areas and survives drought well. Its productivity can be decreased by the leucaena psyllid in humid and subhumid areas. Leucaena esculenta, L. pallida and L. trichandra are all highland species and are more resistant to psyllid attack. Acaciella angustissima grows well, even in low fertility and moderately semi-arid areas. Calliandra calothyrsus is less drought tolerant and $G$. sepium is less cold tolerant (exhibiting winter dieback but regrowing rapidly). On smallholder farms, these trees are usually grown in dense stands, in 'fodder banks' or in convenient niches, such as along boundaries or contour ridges. This tree fodder is especially appreciated by smallholder dairy farmers as a substitute for commercial dairy meal, used most conveniently as leaf meal.

It is possible to effectively use forage legumes in commercial warm-season, subtropical, tropical rangeland and pasture systems. Key aspects of these successes emphasise germplasm, management and continued technical support, which addresses:

(1) ease of adoption and commercialisation

(2) economic incentives

(3) persistent germplasm

(4) adaptive technology

(5) flexible response to local natural and socioeconomic conditions and changes (Muir et al. 2014).
Poor availability of seed has been widely recognised as a hindrance to adoption (Kulich and Kaluba 1985; Timberlake and Dionisio 1985; Mupangwa 1994), with little improvement over the years, as well as inadequate training of extensionists (Kulich and Koluba 1985). Mapiye et al. (2006a, 2006b) concluded that enhanced smallholder awareness through a variety of innovative approaches could greatly enhance adoption. Research efforts have become more focused on smallholder farmers, with their mixed croplivestock systems, and the integration of forage legumes into the arable areas.

\section{Water use and requirements of high-value pasture species}

In South Africa, returns generated from animal production enterprises make pastures one of the highest value crops produced under irrigation (Truter et al. 2012). It is estimated that the total area utilised for irrigated pasture production is approximately $16 \%$ of the total area under irrigation (Backeberg et al. 1996). Two grass species, kikuyu and annual ryegrass, in addition to two legume species, white clover and lucerne, are commonly used in most intensive farming enterprises such as dairy, lamb and beef production. Irrigated kikuyu, ryegrass, kikuyu/ ryegrass, ryegrass/clover and kikuyu/clover mixtures, as well as lucerne and/or mixtures containing lucerne, form an important component of the fodder production in South Africa. These pastures are established on marginal soils poorly suited to field, vegetable or other horticultural crops (van Heerden and Durand 1994).

Irrigation water and $\mathrm{N}$ are resources that can be optimised by selecting an appropriate irrigation system, scheduling technique and pasture (i.e. $\mathrm{N}$-fixing legumes and/or species with high water and $\mathrm{N}$ use efficiency). For sustainable pasture production, the best possible fertiliser and water management is required in order to attain high biomass yield with minimum inputs, which maximises profit whilst minimising impact on the environment (Truter et al. 2012). The most appropriate and cost-effective management strategy therefore would be to integrate irrigation and $\mathrm{N}$ input management, since $\mathrm{N}$ and water cannot be managed independently (Rawnsley et al. 2009).

Due to high rainfall variability in southern Africa, pastures can experience drought at any stage of growth. Hence, the yield and nutritive value will be low. Here, an increasing use of irrigated pastures in both the winter rainfall and summer rainfall regions has been reported (Tainton 2000). Supplementary irrigation in summer is usually used for tropical pasture crops, such as kikuyu, when spring rains are late, or during periods of water stress, whereas the production of annual ryegrass pastures during winter is typically under irrigation.

In South Africa, most irrigated pastures need about $1200 \mathrm{~mm}$ of water for a growing season (Dickinson et al. 2004). In summer rainfall regions a rate of $25 \mathrm{~mm}$ week $^{-1}$ of water is used. This amount is commonly determined from a class A evaporation pan, with daily evaporation typically 3-4 mm in the winter (Tainton 2000). Regardless of differences in climatic and soil factors, most agriculturalists recommend $25 \mathrm{~mm}$ irrigation week $^{-1}$ (minus rainfall) for annual ryegrass, to avoid drought (Goodenough et al. 1984; 
van Heerden 1986; Eckard 1989; Harris and Bartholomew 1991; Le Roux et al. 1991). However, according to Steynberg et al. (1993), there is a $20 \%$ variation in production potential of temperate species between seasons, due to weather and rainfall distribution. Therefore, a single set of irrigation norms to schedule irrigation for pastures was insufficient (Steynberg et al. 1993). With reference to irrigation recommendations made from work conducted by de Kock (1978), variable lucerne yields can be obtained by applying anything from 300 to $2400 \mathrm{~mm}$ of water per season. The timing of irrigation according to de Kock (1978) is thus of significant importance (Fessehazion et al. 2014).

Due to the high cost of irrigation water and fertilisers (Tainton 2000), the production of high $\mathrm{N}$ fertilised grass pasture under irrigation is economically discouraging. Therefore, a better management system for pastures is required, and this includes scheduling the irrigation and nutrient requirement of grasses according to their utilisation method and intensity. Reliable information and data pertaining to the water requirements of important grasses and legumes, and mixtures thereof, which are affected by an inorganic form of $\mathrm{N}$ to facilitate the efficient irrigation management of such mixtures is lacking. In semi-arid regions, water is the primary contributor to grassland production (Whitney 1974). The development of well-established pasture requires favourable growing conditions with no water stress. This leads to higher yields and good nutritional quality. In some instances, irrigation may give little or no advantage, especially under hot climatic conditions, where water deficits, even for short periods, limit metabolic processes, which may reduce growth rates. Therefore, the aim of irrigation management is to maintain a favourable supply of water, between the extremes of excessive dryness or wetness, within the root zone (Truter et al. 2012).

Considering temporal and spatial complexity, it is difficult to evaluate the whole system with short-term monitoring experiments. Development of site-specific optimal $\mathrm{N}$ and irrigation management practices requires costly long-term trials. Since it is expensive and impractical to test multiple irrigation and $\mathrm{N}$ application strategies, the use of models can provide great insight and better understanding of the behaviour of the pasture system. Models can also be helpful in selecting best management practices for specific sites and environmental conditions (Fessehazion et al. 2014). Green (1985) estimated the water use and irrigation requirements of pastures for all pasture growing areas of South Africa. According to Green (1985), the water use estimates were developed for any grazed pasture except for lucerne, and could include any kikuyu and ryegrass-based mixed pastures. In South Africa, there is no information relating to water use of specific mixed pastures and this has been identified as a high research priority for the future (Truter et al. 2012).

\section{Drought-tolerant forage species}

Common features of many countries are limited or unreliable rainfall, and for a number of reasons less-developed countries are least able to cope with such a situation (Wotshela and Beinart 2012). Of the world's continental surface, arid and semi-arid regions cover about $30 \%$ of the area, where water is the most important environmental factor limiting plant growth and sustainable production (Rojas-Aréchiga and Vázquez-Janes 2000). Approximately $65 \%$ of the land area in specifically South Africa is classified as arid and semi-arid, with a mean annual rainfall of $500 \mathrm{~mm}$ or less (Snyman 1998). Therefore, when farming under rain-fed conditions, it is important for the available water to be used in the most efficient way and by the most appropriate plants. Given water shortages on arid lands and the threat of climate change, more attention needs to be given to the development of drought-tolerant fodder crops. Since the beginning of the 20th century the establishment of drought-tolerant fodder shrub crops, of which Opuntia spp., Atriplex nummularia and Agave americana are the most important, has been urged to combat the loss of livestock and their products due to periodic droughts experienced throughout the arid and semi-arid areas of South Africa (de Kock 1967). Unfortunately, one century later these valuable sources of fodder still have not been exploited to their full potential by the farming community. Recent literature highlights some of the key aspects of drought-tolerant forage species being researched more intensively in parts of southern Africa.

(1) Opuntia spp. (cactus pear): Cactus pear usually refers to the cultivated spineless cultivars of the cactus Opuntia ficus-indica, of which the spiny variety, as in the case of other Opuntia spp., is known as prickly pear (Zimmermann 2015). Opuntia ficus-indica was introduced to South Africa at least 260 years ago (Oelofse 2002). The plant was carried by settlers to all the arid and semi-arid parts of the subcontinent where it was cultivated as a living fence and for its delicious fruit (Zimmermann et al. 2009). The major source of fodder from cacti in South Africa, however, comes from three cultivars derived from Opuntia robusta, which were developed during the 1920s. These are widely known as the 'bloublad' or 'rondeblad' cactus pear varieties (Zimmermann 2015). They are cultivated exclusively as a fodder plant for the dry and drought-stricken Karoo. Opuntia species are known for the development of physiological, phenological and structural adaptations (Guevara et al. 2011), which make them productive in these drier environments (Nobel and Zutta 2008). Cactus pear (Opuntia spp.), a crassulacean acid metabolism (CAM) plant, with greater conversion efficiency (water into DM) than that of $\mathrm{C}_{3}$ grasses and $\mathrm{C}_{4}$ broadleaves (Galizzi et al. 2004), is therefore particularly attractive as a feed (Nobel 1995) and thus to digestible energy (Nobel 2002). Concerning the interest in desertification (Guevara et al. 2011), climate change (Ash et al. 2012) and the range of economic uses (Snyman et al. 2007), the value of the cactus pear must not be underestimated for the future. On average the biomass generation for cactus pear per unit of water is about three times higher than for $\mathrm{C}_{4}$ plants and five times higher than for $\mathrm{C}_{3}$ plants (Snyman 2013). Rain showers of a few millimetres, which are normally of almost no value to the common fodder plants, can be efficiently used by the cactus pear (Snyman 2006a). This is possible because of its unique, relatively horizontally and shallow spreading 
root system (Snyman 2006b). Cactus pear has also the ability to still withdraw water from the soil at a stage when other crops are unable to (Snyman 2007). Therefore, this crop can utilise the more arid areas to their full potential. Water use efficiency studies on CAM plants under field conditions over a full growing season have not often been reported in the past. This kind of study is of great significance from an agronomic point of view, both in practice and theory (Orona-Castillo et al. 2004). The common opinion that cactus pear needs low inputs to give high yields (fruit and fodder) has been so misconceived that limited scientific information is available to farmers and the importance of appropriate orchard management has been largely neglected (Snyman 2014). Strategically, irrigation could be of great importance for higher production in cactus pear during dry periods (Snyman 2014). A range of economic uses makes cactus pear ideal for agricultural development (Wotshela and Beinart 2012). A recent undertaking in South Africa is commercial cultivation of cactus pear over a wide range of climates (Snyman 2006a). Limited research into this emerging crop has been published, although South Africa hosts one of the largest germplasm collections of cactus pear in the world (Mashope 2007). Global desertification and the declining water resources worldwide (Guevara et al. 2011) is likely to increase the importance of Opuntia spp. as an effective food production system, including both fruit and vegetable parts (Mobhammer et al. 2006). Opuntia cladodes can be used to successfully balance part of livestock's diet (Einkamerer et al. 2009; de Waal et al. 2013). From a well-managed, mature cactus pear plantation of 800 to 1000 plants ha ${ }^{-1}$, one can expect more or less $10 \mathrm{t} \mathrm{ha}^{-1}$ dry mass from the cladodes and $20 \mathrm{t} \mathrm{ha}^{-1}$ biomass from fruits - depending on the cultivar (Fouché and Coetzer 2013).

(2) Atriplex nummularia (oldman saltbush): The species is indigenous to Australia and has been grown in South Africa for the past 150 years (de Kock 1967). It was introduced in the Karoo between 1869 and 1891 (Angua 2005). To date, it still forms part of the fodder flow planning on many Karoo farms. Although in South Africa, with the new legislation on weeds it is categorised as a grade two encroacher plant, it can be cultivated with the necessary permission. For many centuries the marginal lands of the Karoo have been utilised for agriculture, which has led to the degradation of the soil, resulting in cash-crop farming becoming unprofitable (de Kock 1980). Because of the extensive degradation, agricultural extension officers previously encouraged the planting of $A$. nummularia in abandoned fields to cover the soil, relieve the grazing pressure on the indigenous vegetation and provide fodder for livestock (de Kock 1998). Over time, however, A. nummularia has spread to other disturbed areas, especially to the deep alluvial soils along seasonal rivers in the Karoo, posing the threat of potentially becoming invasive to the ecosystem (Angua 2005). About 50 species are recognised as fodder shrubs, of which 15 are cultivated as fodder crops (König 1992). The best-known Atriplex shrub is $A$. nummularia, while Australian creeping saltbush ( $A$. semibaccata) can also be used for grazing (de Kock 1980). They do well in areas where the rainfall is low and variable, where the cultivation of fodder crops is uncertain, and are adapted to a wide range of alkaline and saline soils (Malan 2000). Most research regarding water use efficiency and nutrient value done on this plant took place before 2000 (de Kock 2001). Over the last decade not much additional information on cultivation and productivity has been published in scientific journals. At an age of 15 months, edible DM production can range from $0.7 \mathrm{t} \mathrm{ha}^{-1}(A$. canescens) to $5.8 \mathrm{t} \mathrm{ha}^{-1}(A$. rhagadioides) (Malan 2000). Seasonal DM production (1 600 grazeable plants ha ${ }^{-1}$ ) of between 2 and 4.7 t ha $^{-1}$ can be obtained (de Kock 2001) or 21 sheep ha-1 for four months (Hoon et al. 1998), with an average protein content of 16-22\% (de Kock 2001).

(3) Agave americana (American aloe): It is one of the hardiest plants that can be established for the production of fodder in arid and semi-arid regions (Gentry 1982). It is indigenous to Central America and Mexico, and was introduced to South Africa at the end of the eighteenth century (de Kock 1967). It is related to the sisal plant (but its fibre has no commercial value) and can be of value in the control of erosion when established on the contour, or on eroded patches. It allows water to pass through while much of the soil and debris is kept back, with the result that a contour wall is built up in time (Hoon 1994). It can survive on poor shallow soils but not in shady environments (Nobel and Berry 1985). It is also an extremely efficient water user (de Kock 2001). As it is not generally used as fodder, little has been published over the last two decades regarding its utilisation and nutrient value. Two disadvantages connected with the plant, namely its harvesting, which is labour intensive, and its high water content, have resulted in insufficient intake of DM by animals (Hoon 1994). Agave americana has the same problems as Opuntia spp., namely a relatively good energy content, but a low protein content (Hoon et al. 1998). A leaf yield of from $120 \mathrm{t} \mathrm{ha}^{-1}$ can be expected annually on relatively poor soils (Hoon 1994). In general, A. americana leaves can only be seen as a drought survival fodder crop (supplementary) as it is not able to provide a maintenance ration.

\section{Integrated animal and temperate pasture management systems}

The main focus for farmers producing livestock products from cultivated pastures is to produce sufficient high-quality palatable fodder, which can fulfil the requirements of animals, whilst ensuring that natural resources remain conserved and protected. This has to be managed and achieved in a profitable and sustainable manner in order to compete on world markets. These objectives make cultivated pasture research complex and the endowment of accurate management guidelines for farmers to obtain the expected results difficult. The main reason for this is that scientists in the field of cultivated pastures need to combine soil, plant and animal sciences into practical, sustainable and economically viable pasture systems. 
Research outcomes in the past have assisted farmers to obtain information to assist in decision-making using a variety of readings, for example, taking soil samples (Swanepoel 2014), pasture disc meter readings (van der Colf 2010) or tensiometer readings (Murphy et al. 2014). However, it is also important to relate such measured aspects to definite indicators that can assist them in making reliable decisions in a scientific manner. Cultivated pasture systems in the southern Cape of South Africa, for example, have continuously changed throughout the last 30 years, mostly for environmental or economic reasons. The introduction of permanent irrigation systems during the 1980s made it possible to replace annual winter- and summer-growing pasture species under rain-fed or supplementary irrigation, with mixtures of perennial ryegrass, tall fescue ( $F$. arundinacea), cocksfoot ( $D$. glomerata) and white and red clovers ( $T$. repens and $T$. pratense), respectively, under full irrigation (Botha et al. 2013). The main problem experienced with these pastures was that, over time, the clover component decreased, while unpalatable grass species, specifically tall fescue, increased, in turn resulting in low production per hectare. This adversely affected the quality and cost effectiveness of the pasture system (van Heerden et al. 1989; Botha et al. 2013).

To overcome these challenges, the botanical composition of the pasture was changed to a more palatable perennial ryegrass and clover mixture. However, a combination of the temperate climate of the southern Cape region, irrigation practices and the improvement of soil fertility to meet the requirements of a ryegrass-clover pasture resulted in kikuyu, a subtropical $\mathrm{C}_{4}$ grass, invading the ryegrassclover pastures. This changed the botanical composition, seasonal productivity, quality, palatability and management requirements of the pasture (Botha et al. 2013). Attempts to prevent kikuyu from invading irrigated perennial pasture were not successful, resulting in the first attempts to use kikuyu as a pasture base and strategically over-sow it with ryegrass and/or clover species.

The use of no-till and minimum-till planting methods proved to be economically viable and research then focused on the sustainability of kikuyu-ryegrass-clover systems (Botha 2003). The success of over-sowing practices is dependent on soil fertility, soil moisture content, soil temperature, overshadowing, choice of species or varieties, grazing management and planting methods (Botha et al. 2013; Swanepoel et al. 2014b). This emphasises the importance of researching the plant component as it is incorporated into the production systems. Management of pasture production systems influence many other variables, and by focusing on the interaction between plant and animals, with the aim of reducing input costs and conserving natural resources, will help us understand the systems and provide more practical and accurate explanations for applied research.

As with any other pasture system, the current system and management should continually be adapted to fit the economic and environmental conditions. Recent research has shifted from heavily fertilised and irrigated kikuyuryegrass pastures to the development of kikuyu-based systems that incorporate more stress-tolerant grass species and perennial legumes capable of fixing $N$ (van der Colf and Botha 2014). Scientists and farmers acknowledge that pasture systems should aim to regenerate and preserve soil health to sustain productivity. Previously, pasture research was conducted on the choice of suitable species, stocking density of animals and enhancing the productivity of pastures. The chemical and physical factors of soil also received attention, but research on the biological component of soil was largely neglected. Consequently, there is a relatively limited understanding of how best to use the dynamics and potentials of soil biology to ensure the sustainability of soil systems for agriculture. Soil quality is a good indicator of sustainable land management and reflects the basic capacity of the soil to function. It integrates the chemical, physical and biological processes within soil that are equally important components for sustainability (Swanepoel 2014).

The chemical aspects of soils are well documented and soil chemical imbalances are rectified using established indicators (Eksteen 1969; Beyers 1994). Unfortunately, most of these indicators were compiled years ago on cultivated soil. The question is whether these indicators are still applicable for no-till systems on soil with 3-8\% organic carbon (C) content (Swanepoel et al. 2014a). Although agriculturalists realised that the biological components (living component) of soils are important, the ascertaining thereof was mostly incorrectly based on the organic C content, which relates to the organic matter content and, vaguely, whether there are earthworms present. No indicators are available to allow farmers to identify the biological component and how to rectify it. If it is accepted that soil health is based on the physical, chemical and biological constituents of the soil (Swanepoel et al. 2014a), then it is clear that the soil, as the basis of our planted pasture systems, can hardly be managed in an economical and sustainable way.

A debatable option was always to reduce the $\mathrm{N}$ input of grass pasture by the introduction of legumes into the pasture system (Swanepoel et al. 2011). Research has shown that the introduction of clovers into a grass pasture will reduce $\mathrm{N}$ fertiliser requirement, but in most cases the grass/clover pasture does not utilise water as efficiently as the pure grass pasture and so the grazing capacity is lowered. The production potential of planted pasture in a fodder flow system on farms is based on the selection and effective management of different species within the natural resources on the farm. To ensure that a fodder flow programme is sustainable and profitable, it is best to follow the 'bring-the-plant-to-the-soil' concept. The choice of species is then based on the physical and morphological characteristics of the soil, soil fertility (availability of macroand microelements and organic matter), availability of water, climate (atmospheric pressure, rainfall, temperature, wind and humidity) and fodder flow requirement (Botha 2014).

A sustainable fodder flow system is based on the optimum utilisation of the pasture. It is of utmost importance that management and decision-making factors focus on optimum DM production, quality and the palatability of the pasture. This will influence DM intake and optimise beef or milk production per hectare. To obtain these abovementioned factors, the management practices should be based on appropriate grazing intervals (rotation) and intensity (how short). The availability of pasture should not 
be measured in time or height, but rather by the availability and residual of pasture. The most important management aspects in this regard that are essential for the sustainability of an effective pasture system are based on the frequency and intensity of grazing (Botha 2014).

\section{Conclusions}

In the past 50 years, a wealth of knowledge has been generated on the function and value of our indigenous grass and legume species, especially in our diverse environmental conditions. Exotic species with substantial international research support play a dominant role in integrated pasture and animal production systems. This information support, however, is not adequate for the diverse southern African environmental conditions or cultural practices. The latter confounds the challenge of pursuing food security in a country, particularly in the absence of detailed and holistic understanding of indigenous species or adaptable exotic species required to achieve sustainable solutions and systems.

There are currently several African-bred cultivars available internationally, and seed imported could be of inferior quality. Therefore it may be important to re-evaluate these species from local varieties using the first principles outlined by Barnes et al. (1972). Currently, there is no breeding programme for subtropical forage species and a limited programme for root crops. Many of the existing cultivars of grasses are stored as seed lots and could easily be lost, if not licensed to seed companies. With no newly adapted cultivars coming from South African forage breeding programmes, the existing cultivars may soon reach the end of their productive lifespan.

To date, significant advances have been made in terms of characterising the nutritional and water requirements of pastures in southern Africa. 'Knowledge gaps' do, however, exist on a number of aspects, which are highlighted by some of the more important interrelated research needs, such as:

(1) The development of more reliable $\mathrm{N}$ recommendations for grazed pastures. Such recommendations need to accommodate $\mathrm{N}$ contributions from the resident organic matter, as well as within-season variations in pasture $\mathrm{N}$ demand. A modelling approach would appear to be necessary, with inputs including factors such as soil total $\mathrm{C}$ and $\mathrm{N}$, soil $\mathrm{C}: \mathrm{N}$ ratio, pasture growth rate and inputs of $\mathrm{N}$ from excretal returns.

(2) The impact of nutrient imbalances in pasture herbage on animal health and production. As noted earlier, in many pasture systems excesses of $\mathrm{N}$ and $\mathrm{K}$, and deficiencies of $\mathrm{Ca}$ and $\mathrm{Mg}$, undoubtedly influence animal performances. Research into both the extent and impact of these factors is urgently required, as well as the development of strategies for their mitigation.

(3) The environmental impact of intensive pastures - a particular concern that appears to have been largely ignored in research programmes. Widespread evidence of 'overloading' of pasture topsoils with $P$ and possibly $\mathrm{N}$ implies a potential for significant diffusive losses of nutrients to surface and underground waters. An increased focus on this aspect would appear to be long overdue.
(4) Improved irrigation scheduling for effective irrigation. Considering the increasing shortage of irrigation water, increased cost of $\mathrm{N}$ fertilisers and associated concerns, the need to improve current irrigation and fertilisation guidelines is accentuated. Extensive research on irrigation and $\mathrm{N}$ management of cultivated pastures has been conducted to improve irrigation water and $\mathrm{N}$ efficiency, reduce nutrient losses and increase harvestable yield and quality. To ensure that pasture growth responses reflect the fertilisers and irrigation inputs applied the soil water and $\mathrm{N}$ balances need to be monitored. This can be done accurately in research programmes. Nevertheless, when wanting to improve $\mathrm{N}$ and water management at field level with similar frequent sampling (components of $\mathrm{N}$ and water balance), it becomes expensive, complex, time consuming and impractical.

(5) The identification of legume species that persist and can sustain seed production. Improved animal production systems in tropical and subtropical regions can be achieved when using forage legumes to minimise inputs, such as $\mathrm{N}$ fertiliser and water. In dry-land pastures in subhumid areas forage legumes have proved compatible and replace the $\mathrm{N}$ fertiliser requirement of a pure grass pasture with about $50 \%$ legume in the sward. It was concluded that these dry-land grasslegume pastures grazed for the summer could produce acceptable levels of animal production. The success of these systems will be completely dependent on cultural practices that ultimately influence the plant growth responses and the survival of the species in the system.

(6) Accounting for $\mathrm{N}$ carryover between harvests and/or accounting for mineraliseable $\mathrm{N}$ when introducing $\mathrm{N}$-fixing legume pastures.

(7) Alternative drought-tolerant fodder crops. Drier environments face different challenges, and there is sufficient evidence to suggest that drought-tolerant fodder crops, especially Opuntia spp., A. nummularia and A. americana, can play an important part in limiting shortages of fodder, which result in livestock losses and losses of their products, during droughts in arid and semi-arid areas of South Africa. These crops can utilise the drier areas to their full potential. A range of economic uses makes it ideal for agricultural development and with the declining availability and quality of water resources associated with global desertification, it is imperative that research on these species receive higher priority.

(8) The use of modelling to integrate weather, animal, soil, crop and management practices will become critical.

Plant scientists realise the complexity of animal production from planted pasture and understand the close interaction between various management factors. This understanding remains essential to achieve optimum DM production, quality and palatability of pasture in a quest to produce animal products sustainably within the boundaries of our natural resources. System research emphasises the importance of managing the soil and the need to understand the potential of different plant species contributing to a productive, high-quality fodder flow.

From a management perspective, scientists acknowledge the importance of the measure-to-manage concept. 
However, without well-researched and defined management indicators, the validation of measurements against the critical limits of indicators will not be possible. Practical and reliable scientific research is important for sustainable farming systems. However, future research should also quantify the economic impact of the ecological investment or management practices that result in nutrient losses. In addition, a research priority that will be required to develop rapidly is that of pasture assessment techniques. The digital age is evolving rapidly, and this increasingly provides us with the tools to identify new ways to assess pastures, to communicate results and research outcomes, and to make data universally available for use. The basic understanding of what variables need to be assessed will remain important.

The past 50 years and more of southern African research has provided an enormous wealth of knowledge, and will guide the way forward to develop new insights and understandings of new research questions and priorities that are aligned with global environmental changes and economies. This can only be achieved when international research and developments are studied, understood and aligned with southern African research objectives. To summarise, Table 3 includes, but is not limited to, selected research and development needs based on this extensive review.

The 21st century will definitely embrace many new avenues in the development of pasture and forage science in southern Africa. This can be achieved if the words of Socrates - 'Wisdom begins with wonder' - are remembered.

\section{References}

Acocks JPH. 1953. Veld types of South Africa. Memoirs of the Botanical Survey of South Africa no. 28. Pretoria: Botanical Research Institute, Department of Agricultural Technical Services.

Angua AM. 2005. The story of the old man saltbush in the Karoo. African Wildlife 59: 1-3.

Anon. 1958. Rietondale can help you. Farming South Africa 34: 55-56.

Anon. 1981. Agricultural development program (Natal Region). Pretoria: Department of Agriculture and Fisheries.

Ash A, Thornton P, Stokes C, Togtohyn C. 2012. Is proactive adaptation to climate change necessary in grazed rangeland? Rangeland Ecology and Management 65: 563-568.

Austin NM, Pattinson NB, Bransby DI, Tainton NM. 1981. Sequential estimation of forage dry matter in situ under rapidly changing conditions. Proceedings of the Grassland Society of Southern Africa 16: 95-97.

Backeberg GR, Bembridge TJ, Bennie ATP, Groenewald JA, Hammes PS, Pullen RA, Thompson H. 1996. Policy proposal for irrigated agriculture in South Africa. Discussion document. WRC Report no. KV96/96. Pretoria: Water Research Commission.

Barnes DL. 1973. The soil-plant-animal complex as a conceptual basis for a more effective research. Proceedings of the Grassland Society of Southern Africa 8: 19-22.

Barnes DL, Clatworthy JN, Elliot RC, Rodel MGW, Donaldson CH, Theron EP, l'Ons JH. 1972. Suggested sequence of techniques for evaluating pasture species. Proceedings of the Grassland Society of Southern Africa 7: 156-158.

Bartholomew PE, Miles N. 1982. Factors affecting the nitrogen requirement of pasture grasses in Natal. In: Proceedings of the nitrogen symposium, May 1982. Technical Communication no. 187. Pretoria: Department of Agriculture. pp 122-126.

Beyers CP de L. 1994. Die bemesting van aangeplante weidings.
In: Weidings / Pastures. Elsenburg: Department of Agriculture. pp 86-93.

Birch EB. 1972. Why so little progress with improved pastures? Proceedings of the Grassland Society of Southern Africa 7: $56-60$.

Booysen P de V. 1966. A physiological approach to research in pasture utilization. Proceedings of the Grassland Society of Southern Africa 1: 77-85.

Booysen P de V. 1969. An analysis of the fundamentals of grazing management systems Proceedings of the Grassland Society of Southern Africa 4: 84-91.

Booysen P de V. 1972. Pasture productivity and intensification. Proceedings of the Grassland Society of Southern Africa 7: 51-55.

Booysen P de V, Tainton NM, Foran BD. 1975. An economic solution to the grazing management dilemma. Proceedings of the Grassland Society of Southern Africa. 10: 77-83.

Botha PR. 2003. Die produksiepotensiaal van oorgesaaide kikoejoe-weiding in die gematigde kusgebied van die Suid-Kaap. $\mathrm{PhD}$ thesis, University of the Free State, South Africa.

Botha PR. 2014. Complexity of producing milk from planted pasture. In: Outeniqua Research Farm Information Day proceedings: Milk production from planted pasture, 15 October 2014. George: Western Cape Department of Agriculture. pp 8-11.

Botha PR, Meeske R, Muller CJC, Cloete SWP, Brand TS, de Lange DH, Grwambi B, Monaren N, Burger W, Muller H, Jelander S. 2013. Outeniqua Research Farm: 60 years of excellence: a snapshot of research (1953-2013). Pretoria: AgriConnect Publishers.

Bransby DI. 1984. Grassland research priorities: ideas for the future. Journal of the Grassland Society of Southern Africa 1: 14-15.

Bransby DI, Booysen P de V, Tainton NM. 1977. The evaluation of pastures and grazing management in terms of livestock production. Proceedings of the Grassland Society of Southern Africa 12: 77-82.

Bransby DI, Tainton NM. 1979. A proposed method for determining long term optimum utilization intensities of pastures and veld. Proceedings of the Grassland Society of Southern Africa 14: 49-52.

Bredon RM. 1980. Possible factors responsible for the drop in milk production from kikuyu pastures during late summer and autumn. Natal Agricultural Research Bulletin 8. Pretoria: Department of Agricultural Technical Services.

Broom DN. 1973. A computerised method of pasture planning. Proceedings of the Grassland Society of Southern Africa 8: 53-56.

Burtt-Davy J. 1912. Notes from the botanical experiment station. South African Agricultural Journal 4: 608-611.

Chippendall LKA. 1955. A guide to the identification of grasses in South Africa. In: Meredith D (ed.), The grasses and pastures of South Africa. Parow: Central News Agency. pp 1-530.

Clatworthy JN. 1975. A comparison of irrigated grass-clover and nitrogen-fertilized grass pastures for beef production. Proceedings of the Grassland Society of Southern Africa 12: 51-54.

Clatworthy JN. 1985. Pasture research in Zimbabwe: 1964-84. In: Kategile JA (ed.), Pasture improvement research in eastern and southern Africa: proceedings of a workshop held in Harare, Zimbabwe, 17-21 September 1985. Ottawa: IDRC. pp 25-58.

Clatworthy JN, Holland DGE. 1979. Effects of legume reinforcement of veld on the performance of beef steers. Proceedings of the Grassland Society of Southern Africa 14: 111-114.

Clatworthy JN, Muyotcha MJ. 1980. Effects of legumes sown in reverted veld or in pastures on animal production. In: Annual Report of the Division of Livestock and Pastures, Department of Research and Specialist Services, Ministry of Agriculture, Zimbabwe, 1978-79. pp 174-181.

Cornell HH. 1951. Agricultural Colleges. Cedara College of Agriculture, Natal. Farming in South Africa 26: 281. 
Daphne CW, Zacharias PJK, Hansen AC. 1991. Evaluation of three techniques for measuring grass leaf area. Journal of the Grassland Society of Southern Africa 8: 13-18.

Dannhauser CS. 1988. Review on foggage in the central grass veld with special reference to Digitaria eriantha. Proceedings of the Grassland Society of Southern Africa 5: 193-196.

Davies W. 1968. Pasture problems in South Africa. Proceedings of the Grassland Society of Southern Africa 3: 135-140.

Dickinson EB, Hyam GFS, Breytenbach WAS, Metcalf WD, Basson WD, Williams FR, Scheepers LJ, Plint AP, Smith HRH, Smith PJ, van Vuuren PJ, Viljoen JH, Archibald KP, Els JN. 2004. Kynoch pasture handbook. Maanhaarrand: Kejafa Knowledge Works.

de Figueiredo MCV. 1991. Effect of enzyme additives on kikuyu silage quality. Journal of the Grassland Society of Southern Africa 8: 110-113.

de Kock GC. 1967. Drought resistant fodder crops. Proceedings of the Grassland Society of Southern Africa 2: 147-156.

de Kock GC. 1978. Water requirements of lucerne. Farming in South Africa Leaflet no. 1. Pretoria: Department of Agriculture.

de Kock GC. 1980. Drought resistant fodder shrub crops in South Africa. In: Le Houerou HN (ed.), Browse in Africa, the current state of knowledge: papers presented at the International Symposium on Browse in Africa, Addis Ababa, 8-12 April 1980, and other submissions. Addis Ababa: International Livestock Centre for Africa. pp 399-410.

de Kock GC. 1998. The use of cactus pear (Opuntia spp.) as a fodder source in the arid areas in South Africa. In: Sáenz C (ed.), Proceedings of the international symposium on cactus pear and nopalitos processing and uses. Santiago: Universidad de Chile and FAO International Cooperation Network on Cactus Pear. pp 83-95.

de Kock GC. 2001. The use of Opuntia as a fodder source in arid areas of southern Africa. In: Mondragón-Jacobo C, PerézGonzález S (eds), Cactus (Opuntia spp.) as forage. FAO Plant Protection and Production Paper 169. Rome: FAO. pp 101-105.

de Villiers SR. 1934. The trend of pasture research, with special reference to breeding. Farming South Africa 9: 386-388.

de Waal HO, Combrinck WJ, Fouché HJ. 2013. Preserving masked cactus pear (Opuntia ficus-indica) fruit with wheat straw, maize hay or lucerne hay. Paper presented at the VIII International Congress on Cactus Pear and Cochineal, 28-31 October 2013, Palermo, Italy.

Donaldson CH. 1984. Fifty years of pasture research in South Africa. Journal of the Grassland Society of Southern Africa 1(4): 4.

Donaldson $\mathrm{CH}$ 1990. Effects of seed treatments on the germination of Atriplex nummularia Lindl. Journal of the Grassland Society of Southern Africa 7: 111-115.

du Pisani LG, Knight IW. 1988. Voorlopige evaluasie van Sporobolus fimbriatus as aangeplante weiding in die sentrale oranje-vrystaat. Journal of the Grassland Society of Southern Africa 5:125-129.

Eckard RJ. 1989. The response of Italian ryegrass to applied nitrogen in the Natal Midlands. Journal of the Grassland Society of Southern Africa 6: 19-22.

Eckard RJ. 1990. The relationship between the nitrogen and nitrate content and nitrate toxicity potential of Lolium multiflorum. Journal of the Grassland Society of Southern Africa 7: 174-178.

Eckard RJ, Miles N, Tainton NM. 1988. The use of near infra-red reflectance spectroscopy for the determination of plant nitrogen. Journal of the Grassland Society of Southern Africa 5: 175-177.

Eckard RJ, Dugmore TJ. 1994. Livestock health and production as influenced by nitrogen fertilizer management. Cedara Report N/A/94/3. Pietermaritzburg: Cedara Agricultural Development Institute.

Edwards PJ. 1980. The use of stocking rates/animal performance models in research and extension. Proceedings of the Grassland Society of Southern Africa 15: 73-77.
Eksteen LL. 1969. The determination of the lime requirements of soils for various crops in the winter rainfall region. Fertiliser Society of South Africa Journal 2: 13-14.

Einkamerer OB, de Waal HO, Combrinck WJ, Fair MD. 2009. Feed utilization and growth of Dorper wethers on Opuntia-based diets. South African Journal of Animal Science 39: 53-57.

Fessehazion MK, Annandale JG, Everson CS, Stirzaker RJ, van der Laan M, Truter WF, Abraha AB. 2014. Performance of simple irrigation scheduling calendars based on average weather data for annual ryegrass. African Journal of Range and Forage Science 31: 221-228.

Fouché HJ, Coetzer GM. 2013. Response of cactus pear (Opuntia spp.) biomass production to fruit load. Paper presented at the VIII International Congress on Cactus Pear and Cochineal, 28-31 October 2013, Palermo, Italy.

Galizzi FA, Felker P, Gonzàlez C, Gardiner D. 2004. Correlations between soil and cladode nutrient concentrations and fruit yield and quality in cactus pears, Opuntia ficus-indica in a traditional farm setting in Argentina. Journal of Arid Environments 59: 115-132.

Gammon DM, Twiddy DR. 1990. Patterns of defoliation in four- and eight-paddock grazing systems. Journal of the Grassland Society of Southern Africa 7: 29-35.

Gentry HS. 1982. Agaves of continental North America. Tucson: University of Arizona Press.

Gibbs Russell CE, Smook L. 1980. Names of southern African grasses: name changes and additional species reported since 1955. Proceedings of the Grassland Society of Southern Africa 15: 89-97.

Gildenhuys PJ. 1951. Pasture Research Progress Report no. 3. Unpublished report. Pretoria: Department of Agriculture and Forestry.

Goodenough DCW, MacDonald Cl, Morrison ARJ. 1984. Growth patterns of Italian ryegrass cultivars established in different seasons. Journal of the Grassland Society of Southern Africa 3: 21-24.

Goodenough DCW, Smith A, Morrison ARJ. 1988. Selecting for palatability in Festuca arundinacea Schreb. Journal of the Grassland Society of Southern Africa 5: 186-188.

Green GC. 1985. Estimated irrigation requirements of crops in South Africa. Parts I and II. Pretoria: Department of Agriculture and Water Supply.

Grunow JO. 1966. Objectivity in plant community classification. Proceedings of the Grassland Society of Southern Africa 1: 49-55.

Grunow JO, Rabie JW. 1978. Utilization and preference rating of various subtropical pasture species and mixtures. Proceedings of the Grassland Society of Southern Africa 13: 49-52.

Grunow JO, Rabie JW, Grattarola L. 1977. Standing crop dry matter accumulation and quality patterns of certain subtropical pasture species. Proceedings of the Grassland Society of Southern Africa 12: $37-44$

Guevara JC, Felker P, Balzarini MG, Páez SA, Estevez OR, Páez MN, Antunez JC. 2011. Productivity, cold hardiness and forage quality of spines progeny of the Opuntia ficus-induca $1281 \times$ O. lindheimerii 1250 cross in Mendosa plain, Argentina. Proceedings of the Professional Association for Cactus Development 13: 48-62.

Hall TD. 1934. South African pastures: retrospective and prospective. South African Journal of Science 31: 59-97.

Hardy MB, Gray NN, Mattushek DWA, Griffiths JD. 1990. The performance of beef cows on Digitaria eriantha silage. Journal of the Grassland Society of Southern Africa 7: 144-145.

Harris DI, Bartholomew PE. 1991. The production of four ryegrass cultivars oversown at various seeding rates into irrigated kikuyu. Journal of the Grassland Society of Southern Africa 8: 82-85.

Heard CAH, Wiseman IGR. 1973. Use of annual production curves of pasture species in pasture planning. Proceedings of the 
Grassland Society of Southern Africa 8: 43-46.

Heard CAH, Tainton NM, Edwards PJ. 1984. The contribution of pastures and veld to the feeding of dairy and beef herds in the natal midlands. Journal of the Grassland Society of Southern Africa 1: 37-40.

Henaar JP, Tainton NM, van Ryssen JBJ. 1993. Factors affecting the voluntary feed intake of sheep grazing Pennisetum clandestinum (kikuyu) pastures: observations from forage analysis. African Journal of Range and Forage Science 10: 140-144.

Hoon JH. 1994. Die benutting van Agave americana L (garingboom) as voedingsbron vir skape. MSc thesis, University of the Free State, South Africa.

Hoon JH, Swart JN, King BR. 1998. Benutting van Agave as voedingsbron vir skape. Grootfontein Agric 1: 1-3.

Hyam GFS, Clayton JH. 1968. The response of Eragrostis curvula to nitrogen fertilizer. Proceedings of the Grassland Society of Southern Africa 3: 29-31.

I'Ons IH. 1968. The development of tropical pastures for the Swaziland middle veld. Proceedings of the Grassland Society of Southern Africa 3: 67-73.

I'Ons IH. 1977. Tropical legumes in southern Africa: a review. Proceedings of the Grassland Society of Southern Africa 12 23-27.

Inman-Bamber NG, Tainton NM. 1972. A buoyancy technique for measuring plant volumes. Proceedings of the Grassland Society of Southern Africa 7: 130-132.

Jones RI. 1983. A statistical approach to practical fodder banking. Proceedings of the Grassland Society of Southern Africa 18: 135-139.

Jones RI, Bartholomew PE. 1973. Production curves for pastures and veld. Proceedings of the Grassland Society of Southern Africa 8: 47-52.

Karnezos TP, Tainton NM, Bransby DI. 1988. A mathematical model used to describe animal performance on kikuyu and coastcross II pastures. Journal of the Grassland Society of Southern Africa 5: 38-41.

Kirkman K. 2000. Taking responsibility for the future. African Journal of Range and Forage Science 17: 4-6.

König RKW 1992. Influence of saltbush (Atriplex spp) as a component on performance of sheep and goats under semi-arid range conditions. PhD thesis, Hohenheim University, Germany.

Kulich J, Kaluba EM. 1985. Pasture research and development in Zambia. In: Kategile JA (ed.), Pasture improvement research in eastern and southern Africa: proceedings of a workshop held in Harare, Zimbabwe, 17-21 September 1985. Ottawa: IDRC. pp 163-179.

Le Roux CJG, Howe LG. 1988. A comparison of a number of annual cool season legumes under dryland conditions in the Dohne Sourveld. Journal of the Grassland Society of Southern Africa 5: 143-145.

Le Roux CJG, Howe LG, du Toit LP. 1988. A comparison of the dry matter yields of perennial legumes in the Dohne Sourveld. Journal of the Grassland Society of Southern Africa 5: 146-149.

Le Roux CJG, Howe LG, du Toit LP, Iveson W. 1991. The potential effect of environmental conditions on the growth of irrigated cool season pastures in the Dohne Sourveld. South African Journal of Plant and Soil 4: 165-168.

Le Roux PC, Dannhauser CS. 1999. The influence of rest period during the growing season on the potential of four perennial tropical grass species as foggage. African Journal of Range and Forage Science 16: 19-25.

Maasdorp BV, Jiri O, Titterton M. 2002. Production and utilization of mucuna in Zimbabwe, with emphasis on its use as a feed resource. In: Flores MB, Eilitta M, Myhrman R, Carew LB, Carsky RJ (eds), Food and feed from mucuna: current uses and the way forward: proceedings of a workshop held in Tegucigalpa, Honduras, 26-29 April 2000. Tegucigalpa: International Cover
Crops Clearinghouse. pp 238-256.

Maasdorp BV. 2004. Which trees? (Chapter 2) and Harvesting and conserving tree fodder (Chapter 6). In: Hove L (ed.), Growing trees for profitable milk production. Harare: ICRAF. pp 4-10, 27-29.

Maasdorp BV, Jiri O, Temba E. 2004. Contrasting adoption, management, productivity and utilization of mucuna in two different smallholder farming systems in Zimbabwe. In: Whitbread AM, Pengelly BC (eds), Tropical legumes for sustainable farming systems in southern Africa and Australia. ACIAR Proceedings no. 115. Canberra: Australian Centre for International Agricultural Research. pp 154-163.

Maclaurin AR, Grant PJ. 1987. Research experience of reinforcing veld with legumes in Zimbabwe. In: Kategile JA, Said AN, Dzowela BH (eds), Animal feed resources for small-scale livestock producers: proceedings of the 2nd PANESA workshop, Nairobi, Kenya, 11-15 November 1985. Addis Ababa: International Livestock Centre for Africa. pp 193-207.

Malan PJ. 2000. Selection and propagation of elite Atriplex material. MSc(Agric) thesis, University of Pretoria, South Africa.

Mapiye C, Foti R, Chikumba N, Poshiwa X, Mwale M, Chivuraise C, Mupangwa JF. 2006a. Constraints to adoption of forage and browse legumes by smallholder dairy farmers in Zimbabwe. Livestock Research for Rural Development 18: Article \#175.

Mapiye C, Mupangwa JF, Mugabe PH, Chikumba N, Poshiwa X, Foti R. 2006b. A review of forage legumes research for rangeland improvement in Zimbabwe. Tropical Grasslands 40: 145-149.

Marais JP, Goodenough DCW, de Figueiredo M, Hopkins C. 2003. The development of a Lolium multiflorum cultivar with a low moisture content and an increased readily digestible energy to protein ratio. Australian Journal of Agricultural Research 54: 101-106.

Mashope BK. 2007. Characterization of cactus pear germplasm in South Africa. PhD thesis, University of the Free State, South Africa.

Mentis MT. 1991. Are multi-paddock grazing systems economically justifiable? Journal of the Grassland Society of Southern Africa 8: 29-34.

Miles N. 1986. Pasture responses to lime and phosphorus on acid soils in Natal. PhD thesis, University of Natal, Pietermaritzburg, South Africa.

Miles N. 1991. Nutrition of intensive pastures in the summer rainfall areas of southern Africa. Journal of the Grassland Society of Southern Africa 8: 39-48.

Miles N, de Villiers JF, Dugmore TJ. 1995. Macro-mineral composition of kikuyu herbage relative to the requirements of ruminants. Journal of the South African Veterinary Association 66: 206-212.

Miles N, Dugmore TJ, Mann J. 2005. Minerals in pastures relative to dairy cow requirements and plant growth criteria. Paper presented at the South African Large Herds Conference, Club Mykonos, 21-23 February 2005.

Miles N, Hardy MB. 1999. Soil fertility management in pasture small-plot trials: potential pitfalls. African Journal of Range and Forage Science 16: 101-107.

Miles N, Manson AD. 1992. Considerations on the sustainability and environmental impact of intensive pastures. Journal of Grassland Society of Southern Africa 9: 135-140.

Miles N, Manson AD. 2000. Nutrition of planted pastures. In: Tainton NM (ed.), Pasture management in South Africa. Pietermaritzburg: University of Natal Press. pp 180-232.

Mobhammer MR, Stintzing FC, Carle R. 2006. Cactus pear fruits (Opuntia spp.): a review of processing technologies and current uses. Proceedings of the Professional Association for Cactus Development 8: 1-24.

Mufandaedza OT. 1981. Diet selection by cattle grazing on a high quality legume pasture. Zimbabwe Journal of Agricultural Research 19: 127-128. 
Muir JP. 1993. Establishment and early persistence of ten forage legumes under three grazing regimes in southern Mozambique. African Journal of Range and Forage Science 10: 135-139.

Muir JP, Pitman WD, Dubeux JC Jr, Foster JL. 2014. The future of warm season, tropical and subtropical forage legumes in sustainable pastures and rangelands, African Journal of Range and Forage Science 31: 187-198.

Mupangwa JF. 1994. Fodder production in small-scale and communal sectors of Zimbabwe. In: Mutisi C, Madsen J, Hvlepund $\mathrm{T}$, Gomez M (eds), Proceedings of the Workshop on Integrated Livestock/Crop Production in the Small-Scale and Communal Farming Systems in Zimbabwe, University of Zimbabwe, 26-28 January 1994. Harare: University of Zimbabwe, Department of Animal Science. p 19.

Mupangwa JF. 2000. Effects of supplementing a basal diet of Chloris gayana hay with one of three protein-rich legume hays of Cassia rotundifolia, Lablab purpureus and Macroptilium atropurpureum forage on some nutritional parameters in goats. Tropical Animal Health and Production 32: 245-256.

Murphy M, Botha PR, Truter WF, Swanepoel PA. 2014. On-farm management challenges of irrigation scheduling for planted pastures. Poster presentation at the 49th Annual Grassland Society of Southern Africa Congress, Bloemfontein, 20-25 July 2014.

Muzzell PJ, Booysen P de V. 1969. The use of light-proof boxes for the measurement of plant vigour in cocksfoot (Dactylis glomerata $\mathrm{L}$ ) and lucerne (Medicago sativa $\mathrm{L})$. Proceedings of the Grassland Society of Southern Africa 4: 44-48.

Nash DI, Amman SB, Goodenough DWC. 2008. How much N fertilizer on ryegrass is enough? Dairy Mail 15: 88.

Nobel PS. 1995. Environmental biology. In: Barbera G, Inglese P, Pimienta-Barrios E (eds), Agro-ecology, cultivation and uses of cactus pear. FAO Plant Production and Protection Paper 132 Rome: FAO. pp 36-48.

Nobel PS. 2002. Cacti: biology and uses. Berkeley: University of California Press.

Nobel PS, Berry WL. 1985. Element responses in agaves. American Journal of Botany 72: 686-694.

Nobel PS, Zutta BR. 2008. Temperature tolerances for stems and roots of two cultivated cacti, Napalea cochinillifera and Opuntia robusta: acclimation, light, and drought. Journal of Arid Environments 72: 633-642.

Oelofse RM. 2002. Characterization of Opuntia ficus-indica cultivars in South Africa. MSc thesis, University of the Free State, South Africa.

Orona-Castillo I, Cueto-Wong JA, Murillo-Amador P, SantamariaCésar J, Flores-Hermández A, Valdez-Cepeda RD, GerciaHarnádez JL, Toyo-Diéguez ET. 2004. Mineral extraction of Green Prickly Pear cactus under drip irrigation. Journal of the Professional Association for Cactus Development 6: 90-101.

Parkin DD, Boultwood JN. 1980. Carcass mass gains of steers grazing star grass with different stocking rates and levels of applied nitrogen. Proceedings of the Grassland Society of Southern Africa 16: 51-55.

Pienaar JP, Tainton NM, van Ryssen JBJ, Swiegers JP. 1993. Factors affecting the voluntary feed intakes of sheep grazing Pennisetum clandestinum (kikuyu) pastures: observations in the animal. African Journal of Range and Forage Science 10: 145-150.

Rawnsley RP, Cullen BR, Turner LR, Donaghy DJ, Freeman M, Christie KM. 2009. Potential of deficit irrigation to increase marginal irrigation response of perennial ryegrass (Lolium perenne L.) on Tasmanian dairy farms. Crop and Pasture Science 60: 1156-1164.

Rethman NFG. 1987. The effect of form and level of nitrogen fertilization on the yield of Digitaria eriantha Steud. Journal of the Grassland Society of Southern Africa 4: 105-108.
Rethman NFG, de Witt CC. 1984. The production potential of pure and mixed stands of Eragrostis curvula and Medicago sativa on the Eastern Transvaal Highveld. Journal of the Grassland Society of Southern Africa 1: 30-32.

Rethman NFG, Eden DW, Beukes BH, de Witt CC. 1977. The utilization of Eragrostis curvula and Pennisetum clandestinum pastures for growing out and finishing young beef steers. Proceedings of the Grassland Society of Southern Africa 12: 83-86.

Rethman NFG, Heyns G. 1987. Grazing of Raphanus sativus. L (Japanese radish). Journal of the Grassland Society of Southern Africa 4: 154.

Rhind JMLC, Goodenough DCW. 1976a. The assessment and breeding of Acroceras macrum Stapf. Proceedings of the Grassland Society of Southern Africa 11: 115-117.

Rhind JMLC, Goodenough DCW. 1976b. Midmar-a new diploid Italian ryegrass cultivar. Proceedings of the Grassland Society of Southern Africa 11: 119-121.

Roberts BR. 1967. Pasture quality and its relation to utilization. Proceedings of the Grassland Society of Southern Africa 2: 157-162.

Roberts BR, Scott JD. 1968. The nutritive value, yield and botanical composition of irrigated pastures as influenced by nitrogen fertilizing. Proceedings of the Grassland Society of Southern Africa 3: 83-89.

Robinson J, Clatworthy JN. 1980. Grasses and legumes for pastures. Harare: Natural Resources Board, Department of Natural Resources.

Rojas-Aréchiga M, Vázquez-Janes C. 2000. Cactus seed germination: a review. Journal of Arid Environments 44: 85-104.

Savory R. 1972. Pasture improvement in Malawi: the introduction of legumes into various soil-climate-management ecosystems. Proceedings of the Grassland Society of Southern Africa 7: 87-92.

Scott JD. 1975. Pasture development in South Africa. Fertilizer Society of South Africa Journal 1: 57-61.

Smit GN 1998. Is the grassland scientist becoming an extinct species within the context of scientific research? Journal of the Grassland Society of Southern Africa 15: 72-74.

Smith A. 1977. The evaluation of tropical pasture species in the Transvaal. Proceedings of the Grassland Society of Southern Africa 12: 29-31.

Smith A, Morrison ARJ. 1983. A deep rooted white clover for South African conditions. Proceedings of the Grassland Society of Southern Africa18: 50-52.

Smith A, Rhind JMLC. 1984. Eight decades of pasture plant improvement in South Africa. Journal of the Grassland Society of Southern Africa 1: 25-29.

Smith A, Terblanche CJ. 1994. Lucerne: cultivation and utilization in South Africa. Pretoria: ARC-RFI and National Lucerne Organization.

Snyman HA. 1994. Evapotranspiration, water-use efficiency and quality of six dryland planted pasture species and natural vegetation, in a semi-arid rangeland. African Journal of Range and Forage Science 11: 82-88.

Snyman HA. 1998. Dynamics and sustainable utilization of rangeland ecosystems in arid and semi-arid climates of South Africa. Journal of Arid Environments 39: 645-666.

Snyman HA. 2006a. Root distribution with changes in distance and depth of two-year-old cactus pears Opuntia ficus-indica and $O$. robusta. South African Journal of Botany 72: 434-441.

Snyman HA. 2006b. A greenhouse study on root dynamics of cactus pears, Opuntia ficus-indica and O. rubusta. Journal of Arid Environments 65: 529-542.

Snyman HA. 2007. Root studies on cactus pears, Opuntia ficusindica and $\mathrm{O}$. robusta along a soil-water gradient. Hasseltonia 13: $46-75$

Snyman HA. 2013. Growth rate and water-use efficiency of cactus 
pear Opuntia ficus-indica and O. robusta. Arid Land Research and Management 27: 337-348.

Snyman HA. 2014. Influence of water stress on root development of Opuntia ficus-indica and O. robusta. Arid Land Research and Management 28: 447-463.

Snyman HA, Fouché HJ, Avenant PL, Ratsele C. 2007. Frost sensitivity of Opuntia ficus-indica and $O$. rubusta in a semi-arid climate of South Africa. Journal of the Professional Association of Cactus Development 9: 1-21.

Spear PT. 1985. The influence of pasture legumes on animal productivity. Paper presented at the Grassland Society of Zimbabwe Symposium on Legumes, Henderson Research Station, Mazowe, 26 September 1985.

Steynberg RE, Nel PC, Rethman NFG. 1993. Waterverbruik en waterverbruiksdoeltreffendheid van gematigde aangeplante weidings onder besproeiing. WRC Report no. 257/1/94. Pretoria: Water Research Commission.

Swanepoel PA. 2014. Soil quality of kikuyu-ryegrass pasture in the southern Cape. PhD thesis, University of the Free State, South Africa.

Swanepoel PA, Botha PR, du Preez CC, Snyman HA. 2014b. Impact of cultivation method on productivity and botanical composition of a kikuyu-ryegrass pasture. African Journal of Range and Forage Science 31: 215-220.

Swanepoel PA, Botha PR, Truter WF, Surridge-Talbot AK. 2011. The effect of soil carbon on symbiotic nitrogen fixation and symbiotic Rhizobium populations in soil with Trifolium repens as host plant. African Journal of Range and Forage Science 28: 121-127.

Swanepoel PA, du Preez CC, Botha PR, Snyman HA, Habig J. 2014a. Soil quality characteristics of kikuyu-ryegrass pastures in South Africa. Geoderma 232-234: 589-599.

Tainton NM 1976. The management of sown pastures in Southern Africa. Proceedings of the Grassland Society of Southern Africa 11: 15-17.

Tainton NM, Heard CAH, Nash RC. 1981. Response of Eragrostis curvula to differences in the seasonal distribution of nitrogen fertilizer. Proceedings of the Grassland Society of Southern Africa 16: 71-74.

Tainton NM. 2000. Pasture management in South Africa. Pietermaritzburg: University of Natal Press.

Theron EB, Booysen P de V. 1966. Palatability in grasses. Proceedings of the Grassland Society of Southern Africa 1: 111-120.

Theron JF, van Rensburg WLJ. 1998. The influence of nitrogen and defoliation on production and water-use efficiency of Lolium multiflorum cv. Midmar. African Journal of Range and Forage Science 15: 35-40.

Tidmarsh CE. 1966. Pasture research in South Africa. Proceedings of the Grassland Society of Southern Africa 1: 21-26.

Timberlake J, Dionisio AC. 1985. Review of the use of improved pasture species in Mozambique. In: Kategile JA (ed.), Pasture improvement research in eastern and southern Africa: proceedings of a workshop in Harare, Zimbabwe, 17-21 September 1985. Ottawa: IDRC. pp 143-152.

Titterton M, Maasdorp BV. 1997. Nutritional improvement of maize silage for dairying: mixed crop silages from sole and intercropped legumes and a long season variety of maize. 2. Ensilage. Animal Feed Science and Technology 69: 263-270.
Truter WF, Fessehazion M, Annandale JG. 2012. Review of available knowledge on irrigation system, water management, water requirements and pasture management of selected pastures. Water Research Commission Project K5/2173/4 'Water Utilization in Agriculture' - Water use and crop parameters of pastures for livestock grazing management. South Africa. pp 1-128.

van Denberg M, Kruger AJ. 1989. Plant relations in mixtures of Trifolium subterraneum cv Mt Barker and Lolium multiflorum cv Midmar: I. dry matter production, crude protein content and crude protein production, Journal of the Grassland Society of Southern Africa 6: 23-28.

van der Colf J. 2010. Production potential of kikuyu (Pennisetum clandestinum) pastures over-sown with ryegrass (Lolium multiflorum). MSc (Agric) thesis, University of Pretoria, South Africa.

van der Colf J, Botha PR. 2014. Effect of planting methods on the production potential of perennial grass-clover mixtures planted into kikuyu. Paper presented at the 49th Annual Grassland Society of Southern Africa Congress, Bloemfontein, 20-25 July 2014.

van Heerden JM. 1986. Effect of cutting frequency on the yield and quality of legumes and grasses under irrigation. Journal of the Grassland Society of Southern Africa 3: 43-46.

van Heerden JM, Durand W. 1994. Influence of nitrogen fertilisation on forage and animal production of a continuously grazed irrigated grass/clover pasture in the Rûens area of the southern Cape. African Journal of Range and Forage Science 11: 69-75.

van Heerden JM, Tainton NM. 1987. Potential of medic and lucerne pastures in the rûens area of the southern Cape. Journal of the Grassland Society of Southern Africa 4: 95-99.

van Heerden JM, Tainton NM, Botha PR. 1989. A comparison of grass and grass/legume pastures under irrigation in the Outeniqua area of the southern Cape. African Journal of Range and Forage Science 6: 220-229.

Verschoor A, Rethman NFG. 1992. Forage potential of Japanese radish (Raphanus sativus) as influenced by planting date and cultivar choice. Journal of the Grassland Society of Southern Africa 9: 176-177.

Wassermann VD. 1974. The possibilities of annual medic in the summer rainfall situations. Proceedings of the Grassland Society of Southern Africa 19: 179-184.

West O. 1968. The possibility of using irrigated pastures for the rehabilitation of denuded grazing areas in the Rhodesian Lowveld. Proceedings of the Grassland Society of Southern Africa 35: 95-99.

Whitney AS. 1974. Growth of kikuyu grass under clipping. 1. Effects of nitrogen fertilisation, cutting interval and season on yields and forage characteristics. Agronomy Journal 66: 281-287.

Wotshela L, Beinart W. 2012. Prickly pear: a social history of a plant in the Eastern Cape. Johannesburg: Wits University Press.

Zimmermann HG, Moran VC, Hoffman JH. 2009. Invasive cactus species (Cactaceae). In: Muniappan R, Reddy GVR, Raman A (eds), Biological control of tropical weeds using arthropods. Cambridge: Cambridge University Press. pp 108-129.

Zimmermann HG. 2015. Cactus pear. In: Prinsloo GL, Uys VM (eds), Insects of cultivated plants and natural pastures in southern Africa. Pretoria: Entomological Society of southern Africa. pp 238-343. 